\title{
PEMODELAN DETEKSI KUALITAS TELUR BERBASIS CITRA
}

\author{
Aries Sugihartono \\ Magister Teknik Informatika STMIK AMIKOM Yogyakarta \\ ariessugihartono@gmail.com
}

\begin{abstract}
ABSTRAK
Perkembangan dunia di bidang IT sangatlah pesat seiring dengan berbagai inovasi penerapan di berbagai bidang. Salah satu penerapannya adalah dalam bidang produksi pangan yaitu telur. Menurut data statistik sekjend kementrian pertanian tahun 2012 adalah setiap minggu penduduk per kapita membutuhkan $72 \mathrm{~kg}$ telur ayam lehor.Banyak terjadi ketika konsumen menggunakan produksi pangan ini sudah dalam kondisi tidak layak karena kedaluarsa. Penelitian ini bertujuan membuat pemodelan deteksi kualitas telur berbasis citra yang dapat digunakan untuk mengetahui usia telur. Memang beberapa peniliti sebelumnya juga membuat pemodelan kulitas telur akan tetapi biasanya ditujukan untuk mengetahui apakah dapat ditetaskan atau tidak. Metode penelitian ini adalah action reserach sedangkan untuk pemodelannya peneliti menggunakan metode template matching dengan menggunakan perangkat lunak Matlab. Hasil penelitian ini adalah dapat dibangun pemodelan deteksi kualitas telur berbasis citra dengan obyek pada bagian kantung udara telur. Prosentase hasil keakuratan 62,5\%. Apabila diinginkan prosentase yang lebih besar maka jumlah template harus diperbanyak dan tidak lagi menggunakan toolsakan tetapi dengan sistem codding.
\end{abstract}

Kata Kunci : telur,kantung telur,matlab,template matching.

\section{PENDAHULUAN}

\section{Latar Belakang}

Menurut informasi dari pusat data dan system informasi pertanian sekjend kementrian pertanian tahun 2012 yang menyatakan bahwa konsumsi telur masyarakat kita adalah 72 (kg/kapita/minggu ) sehingga dapat diartikan kebutuhan akan telur ayam cukup tinggi. Konsumen biasanya mendapatkan telur melalui warung atau toko. Perjalanan telur dari produsen hingga ke warung atau konsumen ternyata membutuhkan waktu yang panjang dan bervariasi mulai hitungan jam sampai berhari-hari. Padahal telur sendiri mempunyai batas waktu penggunaan atau waktu layak konsumsi. Telur yang sudah lama atau berhari-hari 
akan menyebabkan kuning telur rusak, kandungan protein berkurang hingga kondisi terdapat bakal embrio.

Beberapa penelitian yang pernah dilakukan untuk mendeteksi telur kebanyakan bagian yang diamati adalah pada kondisi kuning telur dan akan menghasilkan dua atau tiga kriteria kualitas. Variable data pembanding objek terbatas hanya satu variable untuk satu keadaan yaitu telur infertil atau infertil . Oleh karena itu peneliti merasa perlu untuk melakukan penelitian tentang pemodelan deteksi kualitas telur yang mengamati bagian lain yaitu pada ruang udara serta dengan variable data pembanding lebih dari satu untuk menghasilkan klasifikasi lebih dari tiga kondisi yaitu berupa usia telur.

\section{Rumusan Masalah}

Berdasarkan latar belakang masalah yang telah dipaparkan yaitu penilaian terhadap kualitas telur maka permasalahan yang diangkat adalah :

1. Bagaimana membuat pendeteksi kualitas telur berbasis citra dengan metode template matching untuk memperkirakan usia telur ?

2. Faktor apa yang paling berpengaruh terhadap deteksi kualitas telur yang dilakukan pada bagian kantung udara ?

3. Berapakah tingkat akurasi pendeteksi telur dengan menganalisa bagian kantung udara?

\section{METODE PENELITIAN}

Metode penelitian yang di gunakan dalam penelitian ini adalah action research atau penelitian tindakan dimana peneliti melakukan percobaan dengan membuat prototype untuk di lakukan analisa secara mandiri. Tahapan yang dilakukan pada penelitian ini sesuai dengan metode action research ada lima tahap yaitu:

Metode penelitian yang di gunakan dalam penelitian ini adalah action research atau penelitian tindakan dimana peneliti melakukan percobaan dengan membuat prototype untuk di lakukan analisa secara mandiri. Tahapan yang dilakukan pada penelitian ini sesuai dengan metode action research ada lima tahap yaitu: 


\section{Diagnosing}

Tahap diagnosing dilakukan untuk menganalisa permasalahan yang telah ditentukan yaitu bagaimana membuat sebuah pemodelan deteksi kualitas telur dengan metode action research. Adapun kegiatan yang dilakukan pada tahap diagnosa ini antara lain : review pada perangkat pemodelan dari objek penelitian, melakukan studi literatur untuk lebih menguasai dan memahami dasar- dasar teori dan konsep-konsep yang mendukung penelitian dan berikutnya adalah wawancara pada beberapa stak holder yang berkaitan dengan penggunaan telur.

\section{Action Planning}

Setelah menganalisa permasalahan yang akan diteliti maka penulis selanjutnya membuat rencana tindakan yaitu tahapan - tahapan yang akan dilakukan untuk membuat pemodelan deteksi kualitas telur berbasis citra yang meliputi : identifikasi kebutuhan aplikasi, mendesain system alat pengambil data citra , pembuatan database ( pre prosessing), pembuatan sistem pemodelan dan pengujian sistem, analisis hasil dan evaluating.

\section{Action Taking}

Tahap ini merupakan implementasi dari rencana yang telah dibuat pada tahap action planning .

\section{Evaluation}

Pada tahap ini dilakukan evaluasi terhadap sistem yang telah diimplementasikan untuk mengetahui adanya bug dan error, serta mengetahui apakah sistem yang dibuat sudah sesuai dengan yang diharapkan atau belum.

\section{Learning}

Dari hasil evaluasi dapat dibuat kesimpulan bahwa pemodelan dalam penelitian ini apakah sesuai dengan yang direncanakan dan apakah mempunyai tingkat keakuratan yang baik. 


\section{HASIL DAN PEMBAHASAN}

Analisis Dan Rancangan System

\section{Analisis Sistem}

Untuk membuat pendeteksi telur hal yang dibutuhkan adalah :

a. Sofware

Sofware utama yang digunakan pada sistem pendeteksi ini adalah Matlab versi R2009a. Kegunaan MatLab secara umum adalah sebagai berikut:

a) Matematika dan komputasi,

b) Perkembangan algoritma,

c) Pemodelan, simulasi, dan pembuatan prototype,

d) Analisa data, eksplorasi dan visualisasi

e) Pembuatan aplikasi, termasuk pembuatan antaramuka grafis.

Untuk Operating system versi ini support dengan windows XP, windows tujuh dan juga windows delapan.

b. Hard ware

Kebutuhan hardware yang digunakan untuk mengambil data citra meliputi :

1. Webcam untuk mengambil data citra telur

2. Lampu LED 9 watt

3. Kotak input data (box pengambil citra)

4. Personal computer

5. Sumber tegangan 220 volt

6. Telur lehorn 
2. Rancangan System

a. Pre prosessing

Pre prosesing yaitu prosses pembuatan database template image telur dengan alur langkah seperti pada gambar 3.1.

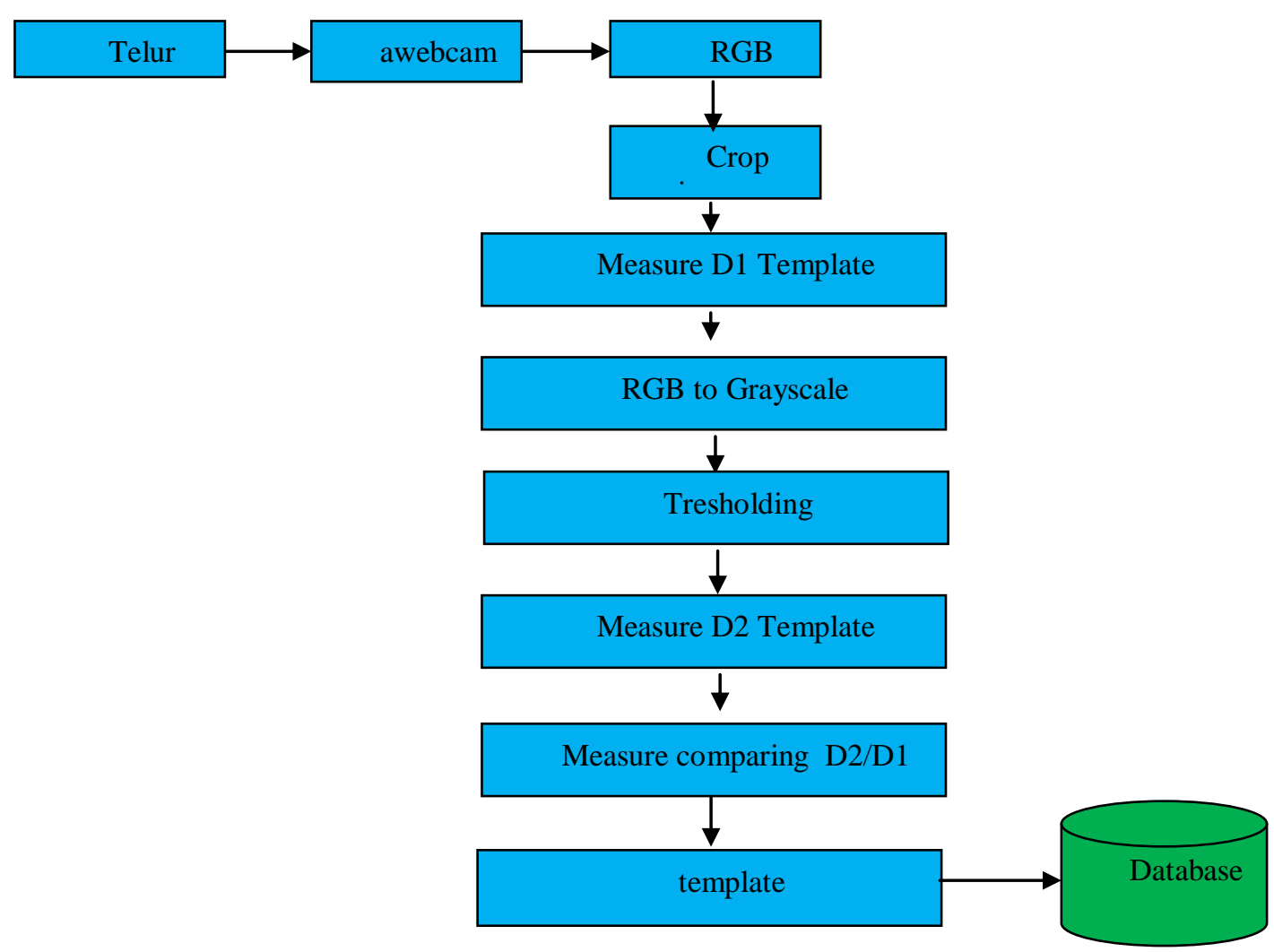

Gambar 3.1. Proses pembuatan database

1. Citra telur (eggs) diambil dengan menggunakan kamera (webcam) yang terhubung dengan komputer dan diperoleh citra dengan format RGB.

2. Croping image citra RGB agar lebih jelas untuk pengolahan.

3. Dengan tool dilakukan pengukuran diameter ( D1) citra telur template.

4. Citra RGB diubah dalam greyscale.

5. Tresholding dan pengaturan level kontras.

6. Pengukuran diameter kantung udara ( D2 ) template.

7. Perbandingkan ukuran dimater telur dan kantung udara.

8. Hasil perbandingan disimpan sebagai template dan disimpan dalam data base. 
b. Perangkat keras pengambil citra

Rancangan perangkat keras untuk mengambil data citra telur dapat dilihat dari gambar 3.2.

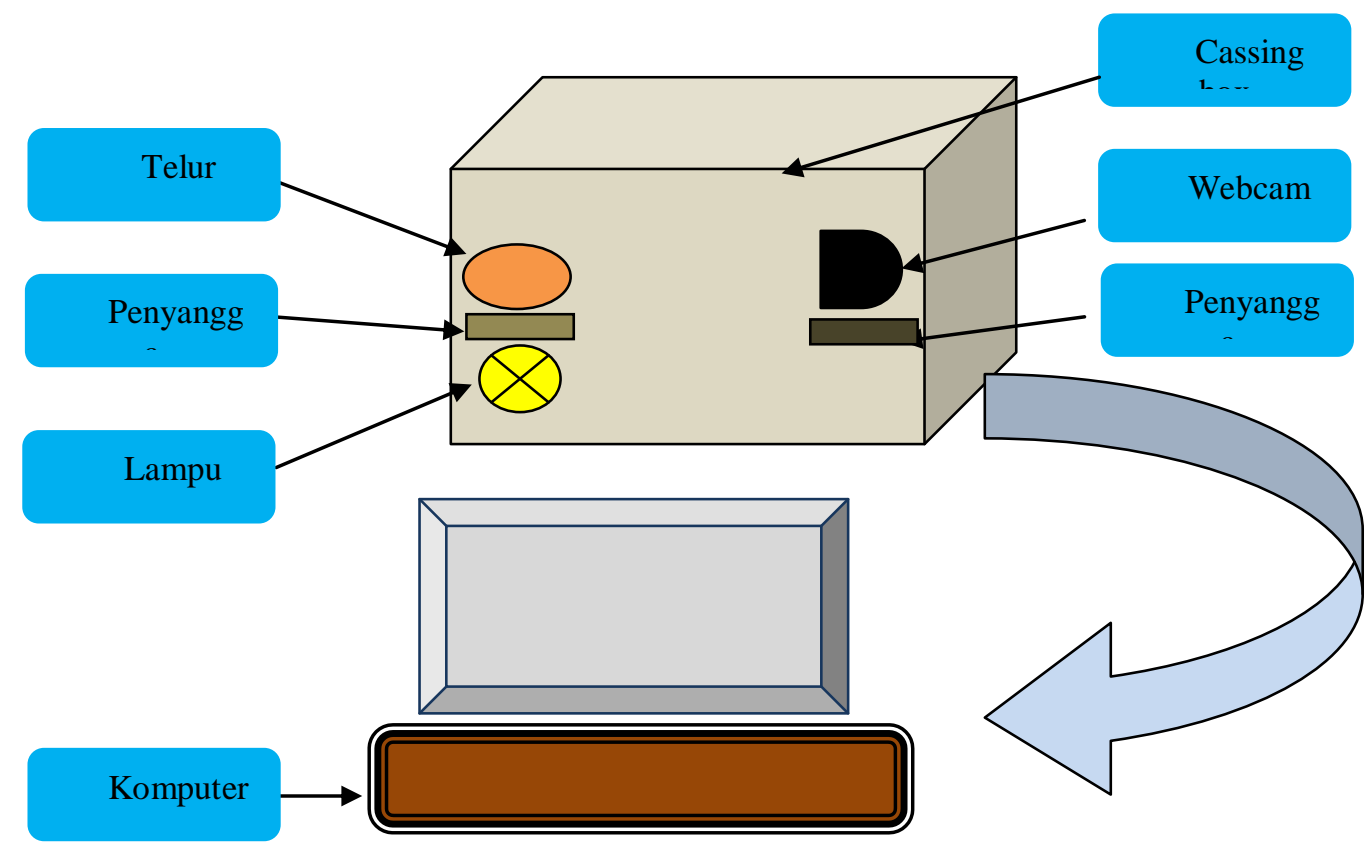

Gambar 3.2. Perangkat alat deteksi telur

Telur sebagai obyek utama penelitian diletakan diatas penyangga berlubang dibagian tengah. Cahaya lampu dengan intensitas yang cukup menerobos lobang mengenai bagian tengah telur. Webcam diberi jarak yang cukup dan lurus terhadap obyek agar memperoleh titik tengah lingkaran telur. Hasil citra langsung dihubungkan dengan komputer untuk pengolahan. 
c. Post Prosessing

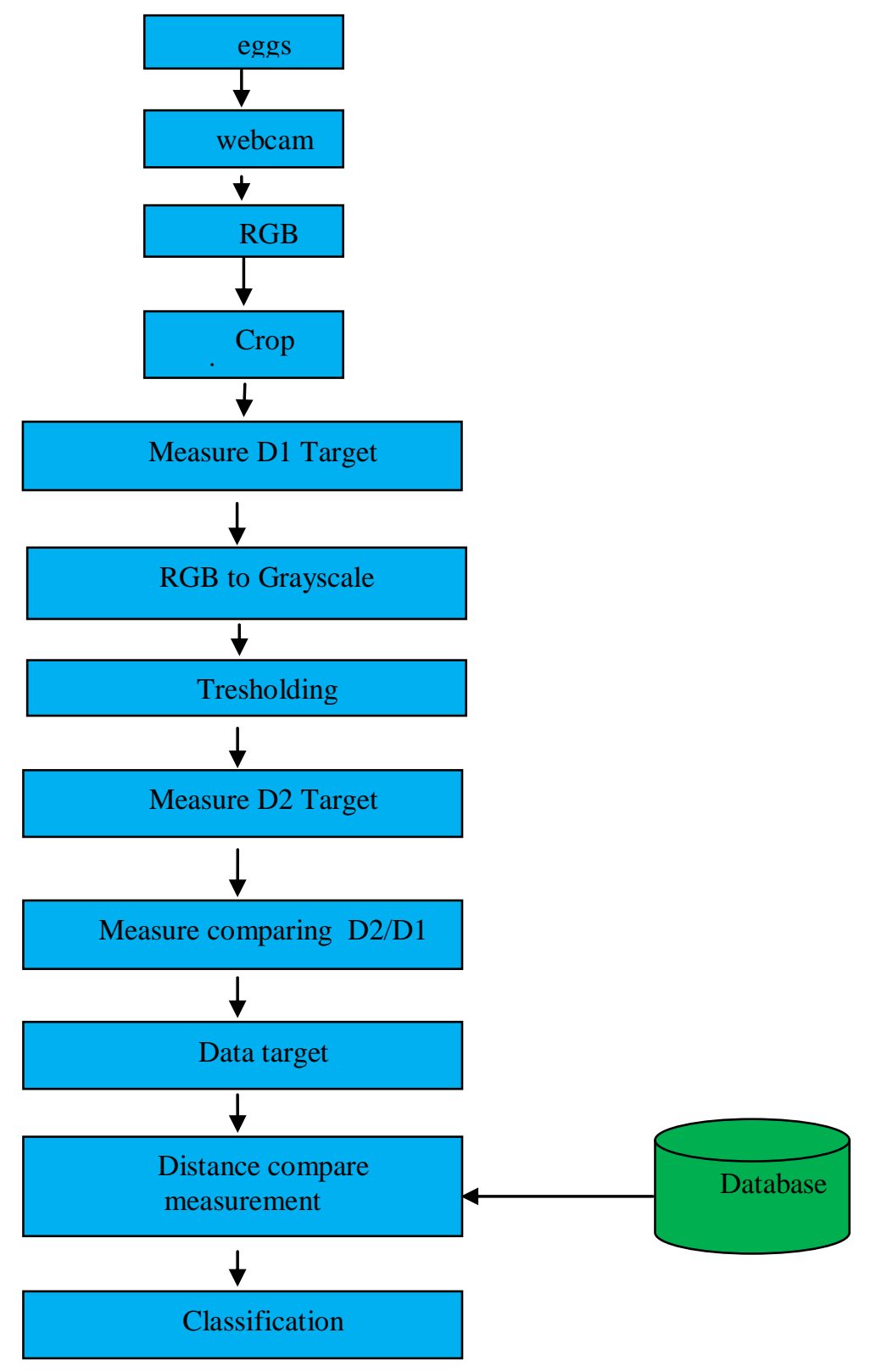

Gambar 3.3. Proses Template Matching 
Pada post prosessing adalah melakukan pekerjaan yang hampir sama dengan pre prosessing, akan tetapi perbedaannya terletak pada objek yang diambil datanya adalah telur yang akan diklasifikasi usianya. Kemudian pada tahap akhir dilakukan proses pembandingan data atau template sehingga diperoleh data sebagai acuan kedekatan dengan data template dengan hasil mendekati nilai nol (0) baik nilai positif maupun negatif.

\subsection{Implementasi}

\section{a. Capture telur template}

Obyek telur yang dijadikan template diambilkan data telur yang berusia 1 hari di capstur hingga usia 20 hari dengan jumlah 3 buah dan didapatkan data image dengan menggunakan webcam dan hasil contohnya seperti pada gambar berikut :
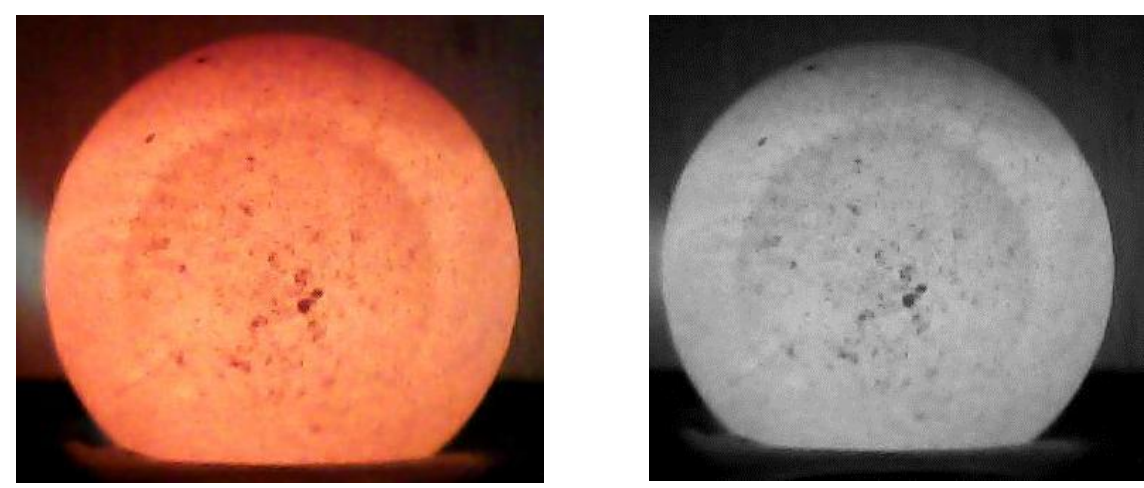

Gambar 3.4. Input citra telur template A usia 20 hari

b. Pengolahan citra template

Untuk proses pengolahan citra template dilakukan dengan mulai menjalankan program Matlab, memasukan image dalam program, rgb croping, measure diameter telur, transform gray scale, tresholding image dan measure diameter kantung udara.

Contoh coding program memasukan citra gambar ke Matlab dan hingga pengolahan dengan tools adalah sebagai berikut :

\section{; Telur A}


A20=imread('2hr20.jpg');

imtool(A20);

A20g=rgb2gray (A20);

imtool(A20g);

Contoh hasil data dari pengolahan citra dan pengukuran dengan tools dapat dilihat pada gambar 3.5.
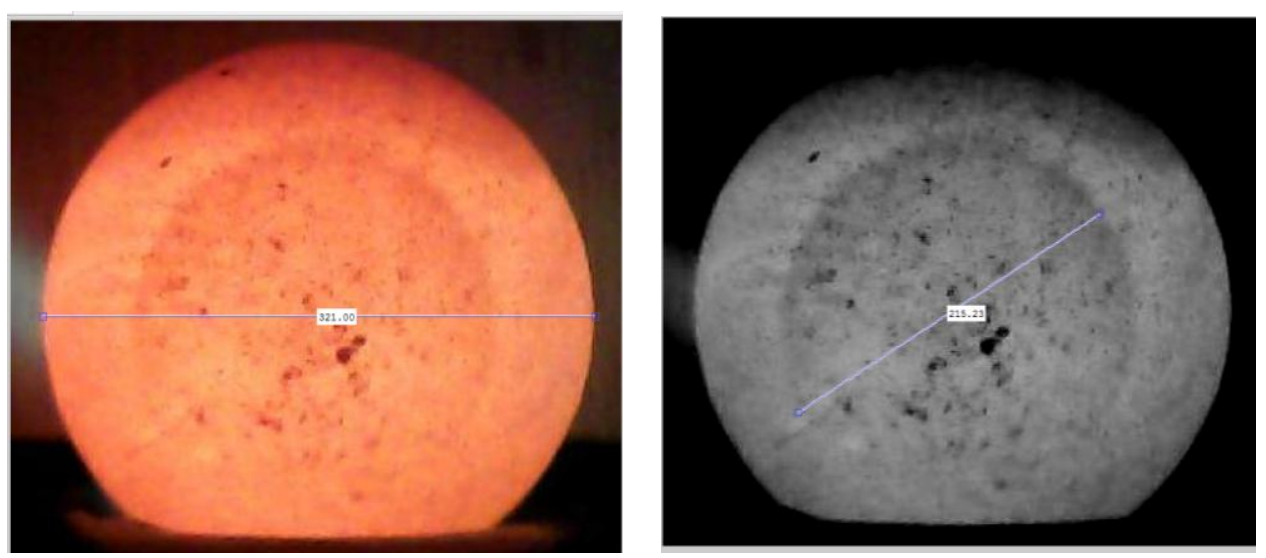

Gambar 3.5. Template

c. Capture Image target

Untuk image target sampling penulis mengambil data 7 buah image sampling dengan variasi hari yang berbeda sebagai contoh pada gambar 3.6 berikut :
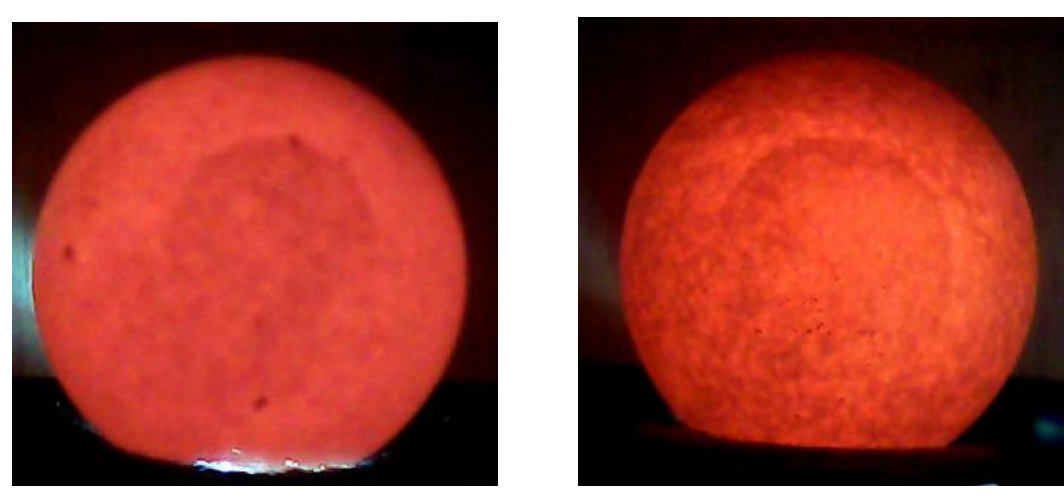

Gambar 3.7. Citra Target

\subsection{Pengolahan Data}

Dari hasil implementasi dan pengujian diperoleh beberapa data yang yaitu panjang diameter telur dan kantung udara. Dengan membagi atau 
membandingkan antara diameter kantung dan telur maka diperoleh nilai yang dijadikan acuan untuk template. Hasilnya dapat dilihat pada masingmasing tabel 3.1.

Tabel 3.1. Template Telur A

\begin{tabular}{|r|r|r|r|r|r|}
\hline No. & Nama & Hari ke.. & Diameter telur & Diameter kantung udara & Diameter kantung/ telur \\
\hline 1 & A & 1 & 357 & 116,36 & 0,325938375 \\
\hline 2 & A & 2 & 382 & 147,61 & 0,386413613 \\
\hline 3 & A & 3 & 353 & 164 & 0,464589235 \\
\hline 4 & A & 4 & 315 & 138,62 & 0,440063492 \\
\hline 5 & A & 5 & 320 & 163,87 & 0,51209375 \\
\hline 6 & A & 6 & 319,01 & 169 & 0,529763957 \\
\hline 7 & A & 7 & 320 & 172,9 & 0,5403125 \\
\hline 8 & A & 8 & 319 & 176,21 & 0,552382445 \\
\hline 9 & A & 9 & 319 & 178,73 & 0,560282132 \\
\hline 10 & A & 10 & 321 & 186,72 & 0,581682243 \\
\hline 11 & A & 11 & 320 & 188,79 & 0,58996875 \\
\hline 12 & A & 12 & 320 & 192,85 & 0,60265625 \\
\hline 13 & A & 13 & 322 & 196,79 & 0,611149068 \\
\hline 14 & A & 14 & 322 & 199,02 & 0,618074534 \\
\hline 15 & A & 15 & 322 & 201 & 0,624223602 \\
\hline 16 & A & 16 & 319 & 205 & 0,642633229 \\
\hline 17 & A & 17 & 321 & 214 & 0,666666667 \\
\hline 18 & A & 18 & 323 & 216 & 0,66873065 \\
\hline 19 & A & 19 & 321 & 215,23 & 0,66875 \\
\hline 20 & A & 20 & & & 0,670498442 \\
\hline
\end{tabular}

Untuk menguji hasil deteksi telur maka dilakukan pengolahan hasil data sampling yang telah diambil capsture imagenya. Beberapa image telur target dengan berbagai variasi usia . Hasil pengukuran akan dibandingkan jaraknya dengan image template yaitu dengan operasi pengurangan terhadap image A,B dan C. Secara ideal didapatkan nilai angka nol (0) untuk matching jaraknya (eucledian), akan tetapi pada kenyataannya hanya dicari nilai yang mendekati angka nol baik bilangan positif maupun negatif. Untuk menganalisa data penulis menggunakan data S1 sampai dengan S7 yaitu hasil sampling image target 1 hingga 7. 
Tabel 3.2. Data uji sampling S1

\begin{tabular}{|c|c|c|c|c|c|c|c|c|c|c|}
\hline N0 & Sampling & Template A & Template B & Template C & S1-A & Matching & S1-B & Matching & S1-C & Matching \\
\hline 1 & 0,495775076 & 0,325938375 & 0,281448468 & 0,377650131 & 0,169836701 & tidak & 0,214326608 & tidak & 0,118124945 & tidak \\
\hline 2 & 0,495775076 & 0,386413613 & 0,407622739 & 0,459358025 & 0,109361463 & tidak & 0,088152337 & tidak & 0,036417051 & tidak \\
\hline 3 & 0,495775076 & 0,464589235 & 0,428324176 & 0,492137203 & 0,031185841 & tidak & 0,0674509 & tidak & 0,003637873 & ya \\
\hline 4 & 0,495775076 & 0,440063492 & 0,4928125 & 0,504398827 & 0,055711584 & tidak & 0,002962576 & ya & $-0,008623751$ & tidak \\
\hline 5 & 0,495775076 & 0,51209375 & 0,531957187 & 0,546807447 & $-0,016318674$ & ya & $-0,036182111$ & tidak & $-0,051032371$ & tidak \\
\hline 6 & 0,495775076 & 0,529763957 & 0,528049536 & 0,549351032 & $-0,033988881$ & tidak & $-0,03227446$ & tidak & $-0,053575956$ & tidak \\
\hline 7 & 0,495775076 & 0,5403125 & 0,566707317 & 0,550115942 & $-0,044537424$ & tidak & $-0,070932241$ & tidak & $-0,054340866$ & tidak \\
\hline 8 & 0,495775076 & 0,552382445 & 0,57154321 & 0,570373563 & $-0,056607369$ & tidak & $-0,075768134$ & tidak & $-0,074598487$ & tidak \\
\hline 9 & 0,495775076 & 0,560282132 & 0,569702381 & 0,585142857 & $-0,064507056$ & tidak & $-0,073927305$ & tidak & $-0,089367781$ & tidak \\
\hline 10 & 0,495775076 & 0,581682243 & 0,635365854 & 0,594202899 & $-0,085907167$ & tidak & $-0,139590778$ & tidak & $-0,098427823$ & tidak \\
\hline 11 & 0,495775076 & 0,58996875 & 0,60665625 & 0,626558824 & $-0,094193674$ & tidak & $-0,110881174$ & tidak & $-0,130783748$ & tidak \\
\hline 12 & 0,495775076 & 0,60265625 & 0,61190184 & 0,65199848 & $-0,106881174$ & tidak & $-0,116126765$ & tidak & $-0,156223404$ & tidak \\
\hline 13 & 0,495775076 & 0,611149068 & 0,62635514 & 0,656395349 & $-0,115373992$ & tidak & $-0,130580064$ & tidak & $-0,160620273$ & tidak \\
\hline 14 & 0,495775076 & 0,618074534 & 0,63107362 & 0,657942029 & $-0,122299458$ & tidak & $-0,135298544$ & tidak & $-0,162166953$ & tidak \\
\hline 15 & 0,495775076 & 0,624223602 & 0,640031056 & 0,659971014 & $-0,128448526$ & tidak & $-0,14425598$ & tidak & $-0,164195939$ & tidak \\
\hline 16 & 0,495775076 & 0,642633229 & 0,654627329 & 0,660724638 & $-0,146858153$ & tidak & $-0,158852253$ & tidak & $-0,164949562$ & tidak \\
\hline 17 & 0,495775076 & 0,666666667 & 0,662283951 & 0,67130814 & $-0,170891591$ & tidak & $-0,166508875$ & tidak & $-0,175533064$ & tidak \\
\hline 18 & 0,495775076 & 0,66873065 & 0,670217391 & 0,677014493 & $-0,172955574$ & tidak & $-0,174442315$ & tidak & $-0,181239417$ & tidak \\
\hline 19 & 0,495775076 & 0,66875 & 0,684294671 & 0,692025291 & $-0,172974924$ & tidak & $-0,188519595$ & tidak & $-0,196250215$ & tidak \\
\hline 20 & 0,495775076 & 0,670498442 & 0,688602484 & 0,694344023 & $-0,174723366$ & tidak & $-0,192827408$ & tidak & $-0,198568947$ & tidak \\
\hline
\end{tabular}

\subsection{Analisis Hasil}

Dari pengujian dan pengolahan data dapat dianalisa beberapa hal yaitu :

a. Penambahan diameter kantung udara per hari mengalami kenaikan dan secara grafik dapat dilihat pada gambar 3.8 dibawah ini :

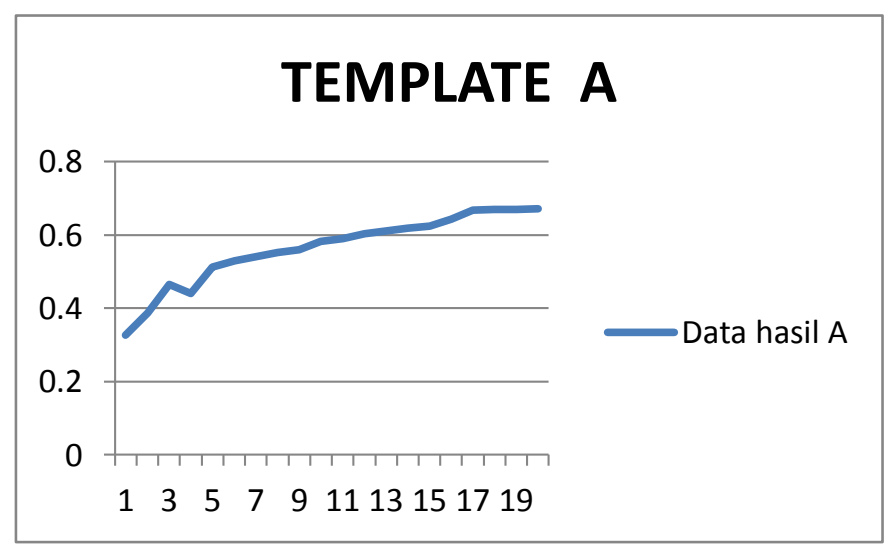

Gambar3.8. Grafik Telur A 
b. Tingkat keakuratan atau ketepatan

Untuk ketepatan dapat dibandingkan dari image telur yang belum diketahui usianya kemudian dibandingkan dengan usia aslinya.Hasilnya dapat dilihat pada tabel 3.12 dibawah ini :

Tabel 3.3. Tingkat keakuratan target

\begin{tabular}{|c|c|c|c|c|c|}
\hline No & $\begin{array}{l}\text { Komponen yang } \\
\text { diuii }\end{array}$ & Template & $\begin{array}{l}\text { Hasil yang } \\
\text { diharapkan }\end{array}$ & \multicolumn{2}{|c|}{ Hasil Pengujian } \\
\hline \multirow{3}{*}{1} & \multirow{3}{*}{ S1 } & A & 5 Hari & 5 Hari & Tepat \\
\hline & & $B$ & 5 Hari & 4 Hari & -1 \\
\hline & & $C$ & 5 Hari & 3 Hari & -2 \\
\hline \multirow{3}{*}{2} & \multirow{3}{*}{ S2 } & A & 13 Hari & 12 Hari & -1 \\
\hline & & B & 13 Hari & 11 Hari & -2 \\
\hline & & C & 13 Hari & 10 Hari & -3 \\
\hline \multirow{3}{*}{3} & \multirow{3}{*}{ S3 } & A & 20 Hari & 20 Hari & Tepat \\
\hline & & B & 20 Hari & 19 Hari & -1 \\
\hline & & C & 20 Hari & 18 Hari & -2 \\
\hline \multirow{3}{*}{4} & \multirow{3}{*}{ S4 } & A & 17 Hari & 16 Hari & -1 \\
\hline & & B & 17 Hari & 15 Hari & -2 \\
\hline & & $\mathrm{C}$ & 17 Hari & 13 Hari & -4 \\
\hline \multirow{3}{*}{5} & \multirow{3}{*}{ S5 } & A & 15 Hari & 15 Hari & Tepat \\
\hline & & $B$ & 15 Hari & 12 Hari & -3 \\
\hline & & C & 15 Hari & 11 Hari & -4 \\
\hline \multirow{3}{*}{6} & \multirow{3}{*}{ S6 } & A & 12 Hari & 12 Hari & Tepat \\
\hline & & B & 12 Hari & 11 Hari & -1 \\
\hline & & $C$ & 12 Hari & 10 Hari & -2 \\
\hline \multirow{3}{*}{7} & \multirow{3}{*}{ S7 } & A & 18 Hari & 16 Hari & -2 \\
\hline & & $B$ & 18 Hari & 16 Hari & -2 \\
\hline & & C & 18 Hari & 13 Hari & -5 \\
\hline \multirow{3}{*}{8} & \multirow{3}{*}{ S8 } & A & 16 Hari & 16 Hari & Tepat \\
\hline & & B & 16 Hari & 15 Hari & -1 \\
\hline & & C & 16 Hari & 11 Hari & -5 \\
\hline
\end{tabular}

Dari hasil tabel diatas maka dengan data 7 buah target sampling, pendeteksi mampu memberi nilai ketepatan atau ke akuratan sejumlah 4 
kali. Jika dihitung secara prosentase maka hasilnya adalah $(5 / 8) * 100 \%=$ $62,5 \%$.

\section{KESIMPULAN DAN SARAN}

Penelitian ini menerapkan inovasi dengan kontribusi utama antara lain :

1. Dengan mengolah citra telur menggunakan webcam dan program Matlab dapat dibuat pendeteksi kualitas telur berdasarkan usia telur.

2. Faktor yang berpengaruh pada pendeteksi kualitas telur berbasis citra pada bagian kantung udara adalah kualitas kamera, pencahayaan yang cukup dan ketepatan pengukuran.

3. Tingkat akurasi pendeteksian objek dengan 8 sampling dan dengan 3 buah template adalah $62,5 \%$.

Dalam penerapan pendeteksi kualitas telur yang lebih teliti maka ada beberapa hal yang dapat dilakukan antara lain :

1. Jumlah template dibuat lebih banyak sehingga nilai akurasi bertambah.

2. Pengukuran objek sebaiknya dan dapat dilakukan dengan coding bukan dengan tools agar ketepatan data lebih bagus.

\section{DAFTAR PUSTAKA}

Ahmad Usman, 2005. Pengolahan Citra Digital dan Teknik Pemrogramannya., Graha Ilmu, Yogyakarta.

Badan Standardisasi Nasional. SNI 01-3926-1995. Telur Ayam Segar untuk Konsumsi. Badan Standardisasi Nasional. Jakarta.

Darma Putra (2010), Pengolahan Citra Digital, ANDY, Yogyakarta.

Egg Weight Estimation by Machine Vision and Neural Network Techniques (A case study Fresh Egg), International Journal of Natural and Engineering Sciences 4 (2): 1-4, 2010,ISSN: 1307-1149, E-ISSN: 2146-0086, www.nobel.gen.tr

Eko Prasetyo (2011), Pengolahan Citra Digital dan Aplikasinya menggunakan Matlab,ANDY, Yogyakarta. 
Gonzales, R., P. 2004, Digital Image Processing (Pemrosesan Citra Digital), Vol. 1, Ed.2, diterjemahkan oleh Handayani, S., Andri Offset, Yogyakarta.

Kementrian Pertanian, 2012, Buletin Konsusmsi Pangan, http://pusdatin.setjen.pertanian.go.id/tinymcpuk/gambar/file/03.BuletinKonsumsiTW2-2013.pdf, diakses 11 Oktober 2015

M.Arif Khabibulloh dkk, 2012, Rancang Bangun system Deteksi Embrio Pada Telur Menggunakan Webcam. Jurusan Fisika, Fakultas Teknologi Industri, Institut Teknologi Sepuluh November, Surabaya.

M.H. Dehrouyeh dkk, 2010, Grading and Quality Inspection of Defected Eggs Using Machine Vision, Sharif University of Technology Tehran, Iran.

Mochammad Hamdani, Luqman Affandi dan Syahminan, 2012, Alat pendeteksi telur menggunakan sensor cahaya dan bahasa C.Teknik Informatika STMIK PPKIA Pradnya Paramita Malang

R.H. SIANIPAR,Pemrograman Matlab Dalam Contoh dan penerapan ,Informatika,Bandung.

Rio mustika santoso , 2012, Fuzzy Decision Tree untuk Analisa Faktor Penentu Kualitas Telur Itik. Program Studi Informatika, Fakultas Teknik, Universitas Widya Kartika Surabaya. A.Al-Marakeby, Ayman A. Alydan Farhan A. Salem, 2013, Fast Quality Inspection of Food Products using Computer Vision.

Raditya Akbar Aman Sancoko dan Eru Puspita, 2011, Pendeteksi Embrio dalam Telur Menggunakan Metode Image Prosesing. Jurusan Teknik Elektronika ,Politeknik Institut Surabaya

Romanoff, A.L. and A.J. Romanoff. 1963. The Avian Egg. John Wiley and Sons, Inc., New York.

Sarwono, B. 1994. Pengawetan dan Pemanfaatan Telur. PT. Swadaya, Jakarta.

Winarno, F.G. 1993. Pangan; Gizi, Teknologi dan Konsumen. PT. Gedia Pustaka Utama. Jakarta.

Winarno, F.G dan Koswana, S. 2002. Telur : Komposisi, Penanganan dan Pengelolaan, Institut Pertanian Bogor, Bogor. 